\title{
The Cartoons of Ollie Harrington, the Black Left, and the African American Press During the Jim Crow Era
}

\author{
James Smethurst and Rachel Rubin
}

"Stark tragedy and humor are separated by a mere hair's breadth. That is why there is so much in Harlem," dryly commented cartoonist Ollie Harrington in an introduction to his role in Harlem's People's Voice, one of two major African American newspapers in New York during the 1940s - the other being the Amsterdam News. ${ }^{1}$ This remark immediately demonstrates what many African American cultural figures - including Virginia Liston (1923), Lead Belly (1935), Langston Hughes (1952), Lester Young (1958), the Isley Brothers (1963), Mississippi Joe Callicott (1967), Son Seals (1980), and Tyler Perry (2011)-have called "laughing to keep from crying." But it also powerfully and efficiently presents comedy as a serious portrayal of social injustices.

Part of the purpose of this essay is to reaffirm Harrington as an important artist of the Black radical tradition in the United States and to extend the work that Brian Dolinar has already done in resituating Harrington's work in the Left milieu that shaped it. ${ }^{2}$ In addition, another goal is to look at how his cartoons, which were more widely circulated among Black readers than any others during the 1930s and 1940s, serve as a sort of metonym for the large and changing influence of the Black Left on the press with significant consequences for African American politics and culture during Jim Crow. There is not nearly enough attention paid to Harrington's cartoons, and the attention he does receive almost always focuses on his most mainstream (and famous) work. Finally, in large part because of Harrington's unusual position as a Black expatriate in the German Democratic Republic, he was able to maintain an openly Black Left stance in his work at a time when many radical African American artists in the United States were 
forced to keep a low profile, or were excluded from the public sphere altogether, due to the Cold War. As Harrington's work kept the faith with the politics of the Popular Front while engaging new currents of Black Power and Black Arts in the 1960s, it can be seen as a bridge between different eras of Black radicalism. ${ }^{3}$

The significance of the Black press is often overlooked when scholars consider the impact of the organized Left, especially the Communist Party of the United States of America (CPUSA), on politics and culture in the United States. With a few exceptions, notably Dolinar's The Black Cultural Front, Bill Mullen's Popular Fronts, and Fred Carroll's Race News, most studies of the African American press give short shrift to the Left. ${ }^{4}$ Similarly, histories of the Communist Left in the United States and its impact on the African American community often pay little attention to Black newspapers. For example, Vernon Pedersen's The Communist Party of Maryland, 1919-1957 concludes that the CPUSA made relatively little headway in Baltimore's African American community, but does not examine the profound CPUSA influence on the Baltimore Afro-American, both an important local and national Black institution and for decades the most consistently left-wing major Black paper in the United States. ${ }^{5}$ In part, this is due to the fact that the apogee of left-wing influence on Black newspapers (and on most African American communities, including Harlem) was in the 1940s rather than in the 1930s, the so-called "Red Decade." The 1940s in Harlem saw the election of local CPUSA leader Benjamin Davis to the New York City Council and the flourishing of the People's Voice, the chief editors of which were Communists. This timeline contradicts the still-common declension narrative following the German-Soviet Non-Aggression Pact of 1939 in histories of the Communist Left in the U.S.

During the extended Popular Front era from roughly 1935 to 1948 (and beyond, in some cases, notably in the pages of the Baltimore Afro-American), the Black Left, through publishers, editors, reporters, cartoonists, and columnists, deeply shaped the trajectory of many major African American newspapers including the Chicago Defender, Baltimore Afro-American, Michigan Chronicle (Detroit), California Eagle (Los Angeles), Pittsburgh Courier, Amsterdam News, Sun-Reporter (San Francisco), People's Voice (New York), and the Boston Chronicle. The Cold War quashed the open expression of this Black Left strain, as these reporters, editors, columnists, and (in the case of Charlotta Bass of the California Eagle) even publishers were driven from their posts by antiCommunism. (The major exceptions were the Baltimore Afro-American and the Sun-Reporter, where leftist publishers George Murphy and his family and Carlton Goodlet could not be dislodged; neither would the African American communities of Baltimore and Washington, D.C. and the San Francisco Bay abandon them.) Nevertheless, the legacies of the radical Black journalism of the Popular Front could not be entirely erased from the Black press and African American politics and culture. These legacies continued, often (but not always) sub rosa, in major Black papers. More open reminders of the Popular Front's impact on the Black press and, through that press, Black politics and culture, appeared in radical 
African American newspapers and journals, such as Freedom, Freedomways, Muhammad Speaks, and the Liberator, increasingly revised and repurposed by the Black Power and the Black Arts Movements at the end of the Jim Crow era. Such reminders also surfaced in other journals and papers, mostly associated with the Communist Left, such as the People's World, The Worker, the Daily World, and the National Guardian.

Harrington's career began in the mass Black press and migrated to more openly radical venues, much as Harrington moved to Paris (where he was close friends with Richard Wright) and then the German Democratic Republic under the pressures of Jim Crow and the Cold War. His Dark Laughter (later Bootsie) comic in the Amsterdam News (which later appeared in the Pittsburgh Courier, the Chicago Defender, and syndicated throughout the Black press) was perhaps the most popular strip among African American during the 1930s and 1940s. Bootsie, featuring a portly Black "everyman" in Harlem - basically a forerunner to Langston Hughes's character Simple - won over its audience through its humor, recognizable landscapes and personalities, and sharp social criticism. Hughes, in an introduction to a 1958 collection of Harrington's Bootsie cartoons, called Harrington "Negro America's favorite cartoonist." Harrington also produced comics and drawings in a wide range of genres, including illustrations, editorial comics, a Black adventure strip Jive Gray, paintings, and a brief run of what we would now think of as a serialized graphic novel adaptation of Richard Wright's Native Son in the People's Voice during the 1940s. His cartoons became increasingly and often harshly pointed, as the Cold War and Jim Crow forced him into exile. These strips and editorial cartoons, like the work of such Black radical artists of the extended Popular Front era as Elizabeth Catlett, Langston Hughes, Max Roach, Alice Childress, Lorraine Hansberry, Harry Belafonte, Jackie Ormes, Hazel Scott, and Brumsic Brandon, can be examined as a bridge between different periods of Black cultural radicalism.

Before proceeding, a few general comments about terms and periodization in this essay are in order. While the essay basically covers Harrington's career during the Jim Crow era, like most periods, Jim Crow's start and end dates are variable. One might begin in 1881 with the passage of the first state law segregating transportation in Tennessee; or pick the Plessy v. Ferguson decision in 1896 as the beginning; or Williams v. Mississippi, in 1898, in which the Supreme Court ruled that the various devices used to disenfranchise Black voters were legal; or Woodrow Wilson's segregation of federal employment in 1913. Similarly, the conclusion of Jim Crow is also mutable - if it can be said to have ever completely ended. Is it with the Brown v. Board of Education decision in 1954? The passage of the Voting Rights Act in 1965? This essay takes a long view of the ending of Jim Crow. While undoubtedly the legal underpinnings for segregation had been severely challenged and the infrastructure of the system eroded in many respects during the 1960s, it was not until the 1970s, for example, when school desegregation was seriously undertaken in many school systems from Jacksonville to Boston. For the purposes of this article, we will consider 
the Jim Crow era as running to approximately 1970, ending at about the same time as the high Cold War.

Born in 1912, Harrington grew up in a sort of pocket ghetto in the South Bronx and came of age during the Great Depression when he moved across the river to the cultural, political, and social center of Black life in New York-and, according to some, the world: Harlem. As Michael Denning points out, one of the fundamental motors of the growth of what he calls the "cultural front" of Left influence in art and culture was the tremendous expansion of the mass culture industries in the 1920s and 1930s and the employment of "plebian," "ethnic" Americans in those industries. ${ }^{7}$ While African Americans were substantially excluded from many of those industries, such as film, radio, advertising, and music, except as performers in often very constrained modalities, the Black press provided work for Black writers, editors, visual artists, and other sorts of cultural workers. It is hard to overstate the importance of this press and its reach into the Black community. It needs to be remembered that the so-called "mainstream" press virtually ignored the Black communities of the United States except to report on sensationalized incidents of crime and violence. If one wanted to know what was going on in Harlem - for example, who was getting married, who died, what the Masons and Elks were doing, what civil right demonstrations occurred, what musicians had played or were going to play in local halls and clubs, and so on, as well as national and international news of particular interest to Black people - one read the Amsterdam News and, later, the People's Voice.

The ideological slant and the intensity of the focus on political issues of these papers and journals varied considerably, but all of them were anti-Jim Crow, pro-civil rights, anti-fascist, and anti-colonial — and, as noted above, quite a few had a marked left-wing cast. The Black press provided employment not only to those whom we might consider professional journalists, such as the editor Marvel Cooke at the Amsterdam News and the People's Voice, but also to writers, actors, and visual artists such as Langston Hughes, Melvin Tolson, Ann Petry, Fredi Washington, and Ollie Harrington, who produced columns, sketches, short stories, comic strips, and line illustrations. Some, like the poet Frank Marshall Davis, were both full-time journalists and creative artists. One of the key supports of the Black press was the growth of other African American-oriented genres and media of popular culture (recorded music, film, theater, and, eventually, radio) that advertised in Black papers and journals.

Harrington's Harlem was a vital nexus of Black radicalism in which the Black Left, particularly with the advent of the Popular Front in 1935 (the year that Dark Laughter first appeared), intersected with Black nationalism, primarily Garveyites and what could be thought of as post-Garveyites, in ways that might seem surprising. While the Black Popular Front (or Black cultural front, if one prefers) was a national phenomenon, reaching North and South, active in every city (and many towns and rural areas) with a significant Black population, Harlem was one of the two most prominent epicenters, surpassed only, perhaps, by Chicago's South Side. 
Brian Dolinar suggests that the Black cultural front in Harlem was primarily birthed by the organization of the Amsterdam News by the Committee for Industrial Organization (CIO)-affiliated Newspaper Guild and a subsequent strike in 1935 in which the support of Communists and leftists was crucial, resulting in the radicalization of much of the paper's staff. ${ }^{8}$ This is a bit of an exaggeration since a network of Left cultural and political institutions had already begun to coalesce in Harlem during the early Depression, but Dolinar makes the valuable point that the Black press in Harlem, as elsewhere, was a particularly important node of Black Left cultural activity, both because the press employed radicalized cultural workers in a wide range of genres and media and because it reached a mass Black audience. With the rise of the Popular Front in 1935-36 and the emergence of such groups and institutions as the National Negro Congress, the various Federal Arts Projects of the WPA that employed many Black artists, the Harlem Arts Center led by Augusta Savage and then Gwendolyn Bennett, and the 306 group of artists that met at painter Charles Alston's studio on $143^{\text {rd }}$ Street, this Black cultural front in Harlem really took shape, directly touching the lives of many thousands of Harlemites buffeted by Northern-style Jim Crow, overpriced and substandard housing, unemployment and severe job discrimination, inadequate access to medical services, and extreme and frequent police brutality.

However, contrary to many accounts of the influence of the Communist Left on Black politics and culture, the real heyday of the CPUSA in Harlem (and other Black communities) was the 1940s. In part, this failure to accurately assess the Black Left in the 1940s has to do with the still-powerful narrative of Communist betrayal and decline after the Hitler-Stalin Pact of 1939. Also, the alienation of Richard Wright and Ralph Ellison (though the latter was not a particularly prominent writer at the time) from the CPUSA due to what they saw as a retreat from support of "Negro liberation" in an attempt to build anti-Nazi solidarity during World War II has sometimes been taken to be a larger trend than it was. The early and middle 1940s were the years in which Adam Clayton Powell, Jr., whose early political career was very much a product of the Popular Front, was elected to the New York City Council and then to the U.S. House of Representatives. When Powell left the City Council for Congress, Harlem CPUSA leader Benjamin Davis replaced him, with Powell's support, in 1942. The expansion of CIO unions with significant Black membership, particularly the National Maritime Union (NMU), in the 1940s left a big mark on the Black community in New York, the most important port in the U.S. The NMU's First Vice President, Ferdinand Smith, was a familiar figure on the streets (and in the newspaper columns) of Harlem. The 1940s were a period of intense Left cultural and educational activity in Harlem with schools, theaters, reading series, rallies, exhibitions, bookstores, galleries, and so on. It was also the decade of Paul Robeson's greatest success as a performer and a political figure as well as when he was most prominently associated with Harlem after spending much of the 1930s in the United Kingdom. Harrington was a close friend of Robeson's, who was a key influence on Harrington's ideological journey. 
One of the most important Left initiatives of the 1940s was the founding of the People's Voice newspaper in 1942 by Powell and what was essentially the Harlem Popular Front, largely out of a dissatisfaction with the Amsterdam News's failure to adequately cover the issues facing the Harlem community and Black people generally, as well as its largely anti-labor management. The People's Voice had a decidedly left-wing profile with Powell as the publisher; Doxey Wilkerson, a Communist, as editor-in-chief; and Marvel Cooke, another Communist, as de facto managing editor. ${ }^{9}$ Most of the staff, including writer Ann Petry and actress Fredi Washington, were leftists of one stripe or another. Benjamin Davis was a major, if unofficial, advisor to the paper's editorial direction. In fact, until the unfriendly takeover of the paper by a then decidedly anti-Communist Max Yergan in 1947 as the Cold War began to ramp up, no other major Black paper in the United States, not even the California Eagle or the Baltimore Afro-American, presented such an openly left-wing profile as the People's Voice. Indeed, part of the paper's front page masthead were the words, "A Militant Paper."

Harrington served as the editorial cartoonist to the People's Voice within this Black Left milieu even as he continued to produce Bootsie for the Pittsburgh Courier. Shortly after Harrington joined the People's Voice in 1942, the paper ran a detailed introduction to him by Llewelyn Ransom - an introduction that is quite relevant because, like Harrington's cartoons, at some points Ransom demonstrates the utter seriousness of humor. For instance, he noted that the fact that Harrington was biracial should "help to send the silly adolf to the early grave he faces on the Russian front." 10 Tellingly, the author does not capitalize "adolf" or "hitler" at any point - a strategy for conveying disrespect - and dryly remarks that because Hitler's paintings were recognized as bad, he'd be especially furious about the talented Harrington. The allusion to the "Russian front" in conjunction with the inferred linkage of Nazism abroad and racism at home, recalling Langston Hughes's 1942 poem “Good Morning, Stalingrad," is also a significant reference to the Black Left stance of both Harrington and the paper generally. ${ }^{11}$

At some point in the 1930s or early 1940s Harrington joined the CPUSA. Ellen Perlo, a central and prominent member of the Party's Arts Club in New York, confirms that he was a member, noting, "He had an intense, dark look about him, and his artwork was always full, finished in appearance, never sketchy." 12 Leaving aside the irony of Harrington's work being "never sketchy," Perlo's testimony is evidence of Harrington's organizational commitment to the Left as well as his sentiments, a commitment that is important to recall in terms of Harrington's artistic and personal trajectory. After all, there is no reason that Harrington actually had to join the CPUSA. Many artists and intellectuals lent their support to the Popular Front and its initiatives without doing so. To join the Party and sit through its club meetings (even those of an artists' club) with their discussions of Daily Worker distributions, leaflets, so on, involved a sort of necessary organizational drudgery that only a practical dedication to social change would warrant. 
Harrington's engagement with the organized Left and the CPUSA's Arts Club also reminds us that he was a part of a vital web of Black (and white and Latinx and Asian American) Left visual artists and arts activists that in Harlem included Romare Bearden, Charles Alston (Bearden's cousin by marriage), Augusta Savage, Gwendolyn Bennett, Jacob Lawrence (a student of Alston's), and Georgette Seabrooke Powell. It is striking how important cartooning and graphic art were to this group of Left Black artists. Like the German Expressionists, Alston, Bennett, Lawrence, Bearden, Charles White, and Elizabeth Catlett were all so-called fine artists who had a deep interest in cartoons and the sort of graphic art that could reach a mass audience. This is to say that Harrington's cartooning did not stand outside of "serious" Black visual art; instead, his work formed a vital part of it. Conversely, the work of Catlett, White, Lawrence, et al., cannot be clearly distinguished from the cartoons of Harrington, Jackie Ormes, Brumsic Brandon, and, later, Tom Feelings (a frequent contributor to the journal Freedomways in the 1960s and 1970s). This can be seen in the use of Charles White's work as essentially editorial cartoons in Freedom, a Black Left journal founded by Paul Robeson and Louis Burnham (a Black Communist who was later one of the primary initiators of Freedomways). Harrington served as Art Director of Freedom at the invitation of his old friend and mentor Robeson and was no doubt largely responsible for the appearance of White's work in the newspaper.

With the rise of the high Cold War, Harrington (like many radical Black artists) fled the United States in 1951, settling first in Paris, where he joined a circle of expatriate Black artists and activists, including Richard Wright. With Wright's death (which Harrington believed to be a murder by the U.S. government due to Wright's renewed radicalism and sympathies with the Left), Harrington applied for and received political asylum in the German Democratic Republic (GDR) in 1961, remaining in Berlin for the last four decades of his life. ${ }^{13}$ His fellow artist Elton Fax asserted that Harrington's physical distance from the United States gave him a useful vision, writing, "Because he has put distance between himself and America Ollie is able to clearly see the oppressors in his native land as partners of other oppressors elsewhere. He therefore links his thrusts at the Nixon policies, the C.I.A., and domestic racism to fascism in Europe and Asia and apartheid in Africa." 14

The CPUSA's major newspaper, the Daily Worker, stopped publishing in 1958 under the pressures of the Cold War and internal battles caused by the fallout from Nikita Khrushchev's "secret speech" about Stalin's crimes and the Soviet invasion of Hungary in 1956. When the CPUSA revived its daily newspaper (the Daily World) a decade later, it chose as editor the Black Communist journalist John Pittman, who knew Harrington and his work through both the Left and the Black press. Pittman hired Harrington as an editorial cartoonist for the new Communist daily.

Pittman's move clearly provided Harrington with much-needed income since his Bootsie strip was dropped by the Chicago Defender in the early 1960s under the pressure, Harrington suspected, of the U.S. government. Harrington's work 
for the Communist press allowed him to develop certain aspects of his art that he had only been able to explore to any significant extent during his time with the short-lived People's Voice and Freedom. While Harrington was clearly a part of the cultural and political circles of the Communist Left in Harlem from at least the mid-1930s, his artistic career beginning with his time with the People's Voice marked a new phase in his cartooning, one in which he was operating within a clearly leftwing context and consequently felt free to be as pointed as he wished with a tone that was at least as savage as Goya and George Grosz and other German Expressionist graphic artists - not to mention Charles White, Charles Alston, and Elizabeth Catlett. Earlier, in an interview in Life, he had noted the influence on his own work of El Greco and Thomas Hart Benton, both of whom rejected simple realism and pleasantness. ${ }^{15}$ In that sense, Harrington's later days as a contributor to the Communist press in the U.S. while living in the GDR were more liberating than constraining.

Harrington first developed the character he is most known for, Bootsie, in the Amsterdam News. Starting in 1935, Harrington contributed a comic strip that was ultimately named for that character but was at first called Dark Laughter. The strip's original name is significant because of the tradition in which it places Harrington. "Dark Laughter," along with the title of the collection (explicitly for white people, as its subtitle indicates, and illustrated by Harrington's cartoons), Laughing on the Outside: The Intelligent White Reader's Guide to Negro Tales and Humor, lines Harrington up with a significant historical sweep of writing and naming that refer to laughing as a social and cultural strategy of concealment and misdirection by African Americans. ${ }^{16}$ In addition to Laughing on the Outside, a few examples are Paul Laurence Dunbar's 1896 "We Wear the Mask," which opens with the line, "We wear the mask that grins and lies" and two answer poems, by Maya Angelou (1987) and Tolbert Jones Small (n.d.), ${ }^{17}$ at least two Smokey Robinson songs ("Tears of a Clown," and "Tracks of my Tears"); Amiri Baraka's "Masked Angel Costume: The Sayings of Mantan Moreland" (1996); numerous hip hop songs (a particularly powerful example is the Fugees" "The Mask," in which they rap about needing a mask because "Feds be hawkin' me"); and so forth. ${ }^{18}$ It is, then, noteworthy that in his introduction to a 1958 collection of Harrington's work, called Bootsie and Others, Langston Hughes writes that Harrington's cartoons have the quality of the blues, that "behind their humor lurks the sadness of 'when you seem me laughin', I'm laughin' to keep from cryin'.",19

Langston Hughes also notes that sometimes Harrington's work is "too bitter" for "many whites," but the character of Bootsie became quite familiar in the Black press, and ran for more than twenty years in the Pittsburgh Courier, which had a range of regional versions and was one of the most significant Black papers - both in terms of size and influence. ${ }^{20}$ Harrington published his first cartoon in the Courier in 1938, and would later become a war correspondent for the paper, writing more than fifty articles. He noted quite precisely that this solved an ethical dilemma for him: he was deeply anti-fascist, but balked at the notion of serving in a segregated military. ${ }^{21}$ 
A useful way to explore the overlap between Harrington's artistic and activist roles is by examining the responses he invoked. This sometimes took the form of letters to the editor, including one declaring, "Sirs, I think Ol Harrington's 'spots' are one of the best parts of your paper. And as for Blues in the News-Harrington's cartoon take on a news story - I'd like to stand up and cheer every time the paper comes out. More power to PV and to Ol Harrington's pencil." 22 However, many readers worried that his cartoons would encourage racist responses. For instance, another letter to the editor opens with how much the writer loves the paper. The only disturbing element, she comments, is Harrington's cartoons, whose characters ("pimps, cowards, and other such characters") contribute to the belittling of African Americans that so many white cartoonists already take up. ${ }^{23}$ Indeed, the paper received so much feedback early in its printing of Wright's Native Son-illustrated in a pull-no-punches way by Harrington - that the editors asked readers to send in postcards with their opinions about the printing, and in response, the paper stopped the series very early. Tellingly, most of the respondents who did not want the series to continue were worried about what white Americans would think because of the novel's rough language. A sort of delightful "wink" about this is included in the editorial commentary, which says that they were pulling the series because readers found it to be "too damn profane." 24

One of the most instructive aspects of Harrington's work is the way he tips his hand-emphasizing what culture is for-by repeatedly presenting culture as a potential "shelter" which he makes literal in this space-filler cartoon (Figure 1), from the People's Voice.

Here, a fashion choice that Harrington repeatedly focused on, the zoot suit, provides literal safety in World War II - a war against the Nazis, who, in addition to attacking multiple countries, functioned as a political party that sought to establish Black inferiority. In fact, the establishment of this racial hierarchy happened on both sides: at this time, the U.S. military was still segregated, which Harrington spoke out about, and culture's function as a shelter was particularly true, he instructed, for African Americans involved in the vexed Double V moment. These images - for instance, the one below (Figure 2) that equates racialized murder by Nazis to racialized lynching - were both emblems and strategies of Harrington's broad anti-racist agenda. A central focus of Harrington's was the intersection of police brutality and African American WWII veterans. This cartoon refers directly to the lynching of a man named Cleo Wright on January 25, 1942 in Sikeston, Missouri. He had just been arrested — and shot — for the usual reason: claims that he had assaulted a white woman. When he was brought to the city jail, a mob of about one hundred white men had gathered to lynch him. Although the response to Wright's killing led to the first Department of Justice investigation of a lynching, the killers were found innocent. While Harrington's cartoon depicts Wright's body with a noose still around his neck, he now appears in front of the city's sign, instead of the tree, which is tiny in the background. This invokes the fact that after Wright's lynching, many African Americans fled the town. The visual "rhyming" between the two panels also makes the city's 


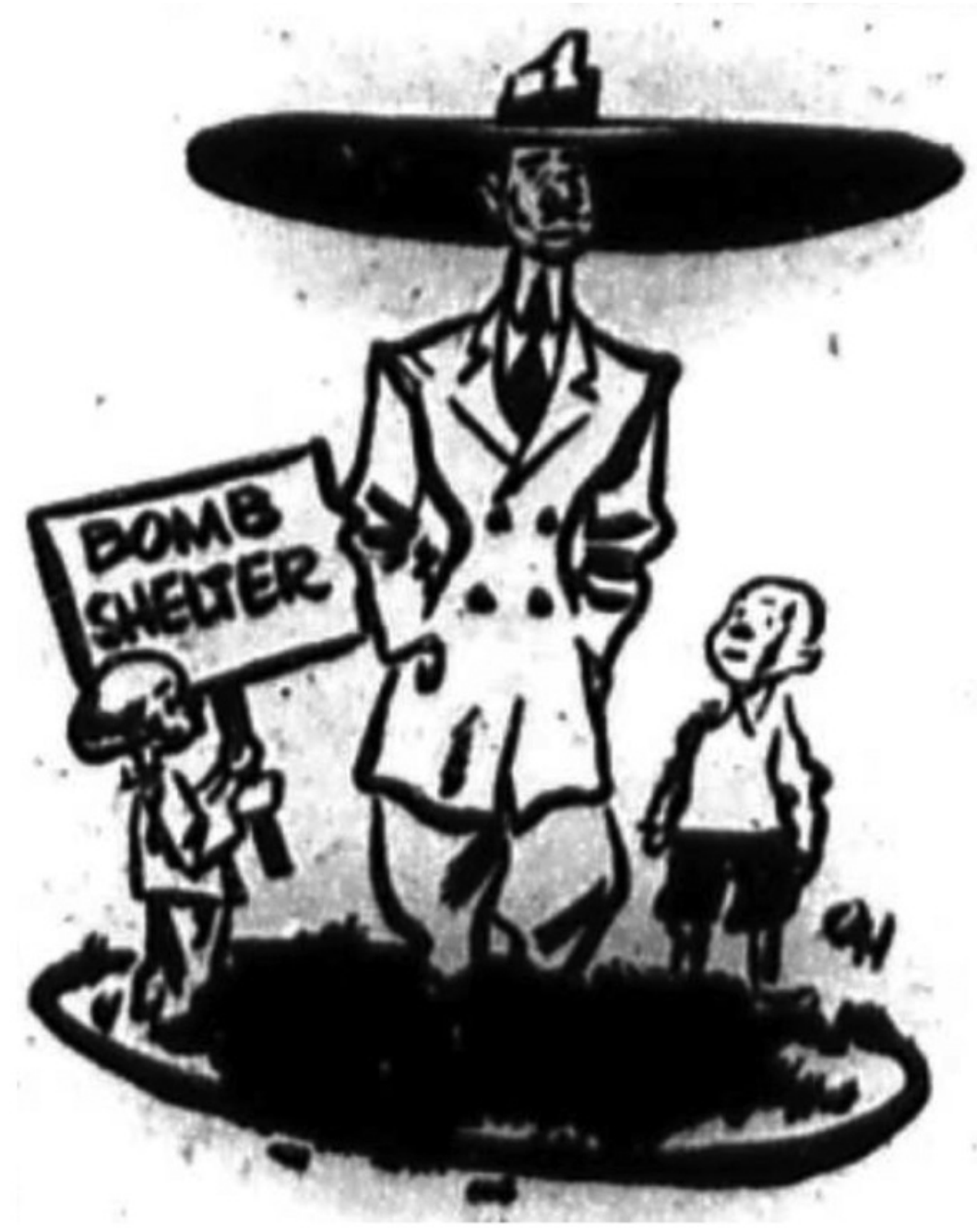

Figure 1: People’s Voice, May 8, 1943, 2.

sign parallel to the sign with a swastika. Furthermore, the emphasis on the letters "U.S.A." - rather than the abbreviation for Missouri, which is not fully visible -asserts that lynching is a national issue, not a regional one.

This comparison of the experiences of African Americans and those of people under Nazism is something Harrington - and, indeed, the People's Voice overall —often took up. Not only did he repeat this side-by-side structure and commentary in another cartoon in this paper, but the comparison is also directly visible in Harrington's cartoon of a veteran in a wheelchair being threatened by a policeman wielding a club. The veteran is asking, "Officer, what Alabama bar 

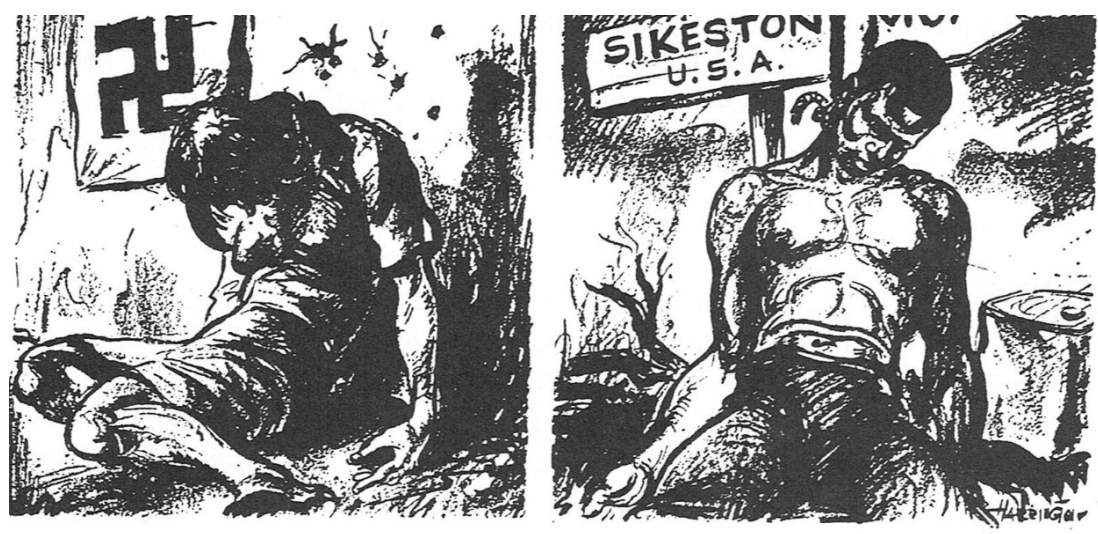

Figure 2: People's Voice, February 28, 1942, 20.

was you holed up in back in ' 44 when I was in Normandy protectin' your civil rights?"25

Having left daily cartooning to work for the NAACP Public Relations Council, Harrington powerfully demonstrated his attention to the Double V campaign in the 1946 pamphlet he wrote about a Columbia, Tennessee riot perpetrated by the police against returning Black veterans. ${ }^{26}$ Harrington was subpoenaed to testify in front of a grand jury - with an unsympathetic judge - about what he wrote in the pamphlet, and was blamed for inflaming public sentiment. The NAACP pamphlet illustrates that Harrington offered impressively astute commentary in multiple forms, not just in his political cartoons, but also in pamphlets, in illustrations of news stories, in small space-fillers (such as the zoot suiter above), in cartoons accompanying subscription forms, and in remarkably perceptive and sly essays. His most biting political cartoons and his sharp attacks on structural racism in the United States, summarized well by his comment, "Black people are all refugees, unless they are African people living in Africa," have not received sufficient recognition. ${ }^{27}$

Of course, one thing that has kept Harrington from receiving this recognition is his relationship with the American Left, particularly with the CPUSA, which some scholars (such as M. Thomas Inge, who edited a collection of Harrington's work and a collection of his essays) try hard to gloss over. For instance, Inge works to expunge Harrington's political beliefs by remarking, with no evidence, that people only read the Daily World for the pictures (including Harrington's cartoons), noting that "one or more of Harrington's cartoons would remain a mainstay of the paper which reached 72,000 readers, many of whom came to look mainly for the cartoons and had less interest in the political content." ${ }^{28}$ In a collection of civil rights-oriented political cartoons for high school students edited by Mary E. Williams, a list of the major places Harrington published excludes the Daily World - but the Harrington cartoon included in the collection is from the Daily World. ${ }^{29}$ Similarly, in the Encyclopedia of Black Comics, Sheena 
C. Howard refers to the New York Daily World but does not identify it as the paper of the CPUSA (though she does address Harrington's closeness to Party members, followed by an unsupported assertion that he was not a member). ${ }^{30}$

In addition to such attempts to purge Harrington's political stances, few people who have usefully paid attention to his cartoons look at them as art and examine them visually; instead, they focus on the captions. While Harrington's artistic strategies are occasionally broadly described (for instance, Howard comments that "Harrington's use of rich pencil shading gave the comic a lush atmosphere and provided gravity to each cartoon"), his individual pieces of work are analyzed infrequently. ${ }^{31} \mathrm{~A}$ category of Harrington's work that has received no attention is his "space-filler" drawings in People's Voice-likely because they are seen as unplanned and off-the-cuff-but as the one above of the zoot suiter indicates, they are actually quite profound. ${ }^{32}$

Roi Ottley, in his 1943 New World A-Coming, writes that the inclusion of Harrington and other Black cartoonists was to "soften the blows dealt by a tough front page," but in fact Harrington's cartoons frequently both worsened the blow and provided self-defense - which is different from softening. ${ }^{33}$ Indeed, the number of Harrington's cartoons that have white men holding a noose contradicts any notion of "softening." A 1973 collection of poster reproductions of Harrington's Daily World cartoons consists of 16 images. One fourth of them have nooses or whips that visually double as nooses, connecting slavery and lynching, as Harrington establishes a range of new ways to "lynch" Black Americans: courtrooms, poverty, political corruption.

As we have mentioned above, Harrington was quite occupied with the Double V campaign, referring, for instance, to the segregated South as a "huge concentration camp." ${ }^{34}$ In a 1942 People's Voice comic (Figure 3), Blues in the News, he has four funny, joking panels, including jokes about zoot suiters, followed by an upsetting image of Black soldiers in a trench, with the words, "We know that our country has been giving our boys a dirty deal but out where they are they need us... and our old pots and pans, discarded sewing machines, and irons will help them pull through. Then we'll all demand a fair share of this democracy they're all blowing off about!"

Here, Harrington makes an immediate gesture toward shaping the cartoon's meaning, as in the first panel, the man who is being thrown on the "scrap pile" is wearing plaid pants that resemble the brick building he is being thrown out of - in short, the country has been built on his labor, but he is being categorized as "garbage." In a deliberately conspicuous way, there is an artistic shift toward realism in the final panel, when he is confronting a reality facing African American soldiers: both the irony of fighting against fascism abroad in a segregated military, but also the need for civil rights work when they come home. Visually, this panel also conveys that the military was still segregated during World War II.

In another cartoon that addresses the contradiction implicit in fighting fascism abroad and maintaining it at home (Figure 4), Harrington tracks African American men trying hard to find employment and being rejected repeatedly, 


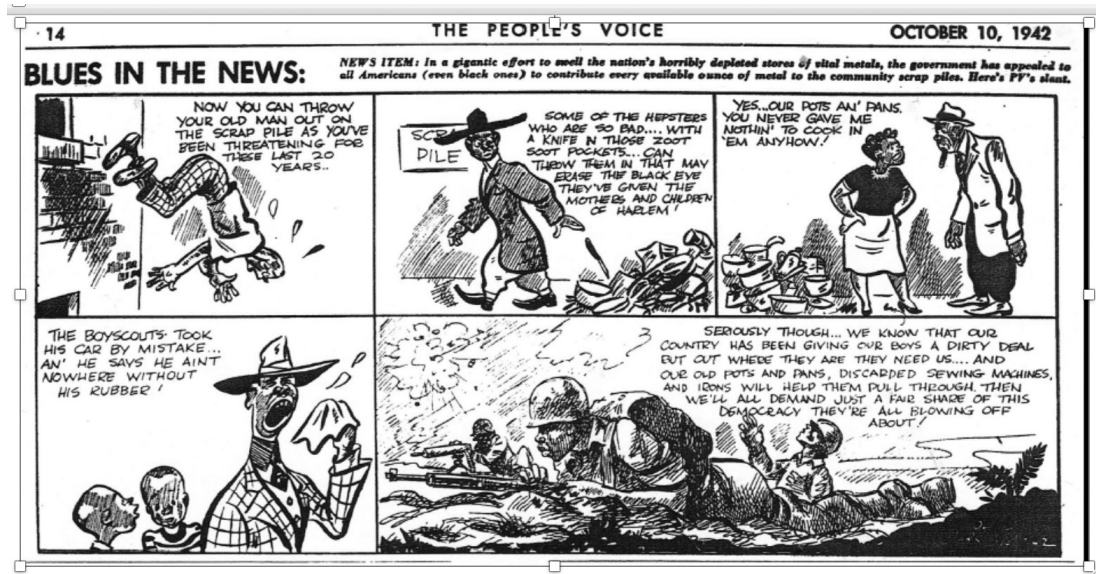

Figure 3: People's Voice, October 10, 1942, 14.

even a disabled man applying for a job particularly for disabled men. In fact, the first panel portrays a man who equates being "colored" with being "crippled."

But the most pointed statement in the cartoon is the blank panel labeled "industrialists with fat war contracts drawing up plans for employing Negro labor." Compared to Harrington's usually dense drawing style, the striking artistic emptiness not only visually represents how white employers discriminate against Black people, but also that art itself is a form of unrecognized labor. Finally, the last panel depicts large Nazis who take up much more space than the unemployed Black men.

In addition to World War II, Harrington uses the Cold War as a way to comment on how institutional racism permeates daily life. In one of the cartoons in the 1958 collection that Langston Hughes introduced (Figure 5), a woman

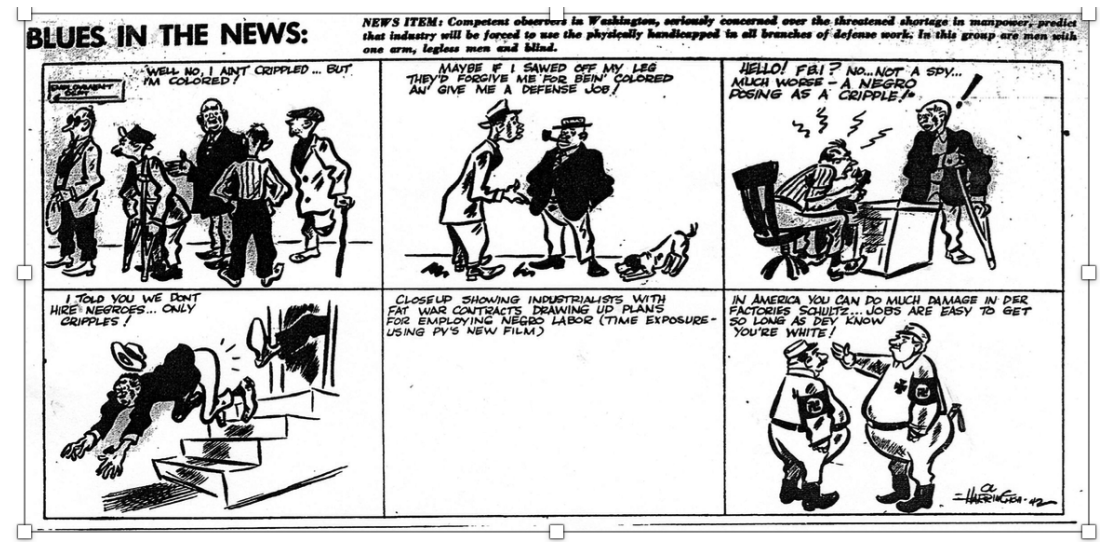

Figure 4: People’s Voice, September 5, 1942, 14. 
speaking to her pastor about the destruction of her home is pictured holding a small child protectively. The woman remarks that she initially thought that the Russians had dropped a bomb on the house, but it turns out that in fact, it was "the white citizens Council" [sic], basically a front for the Klan, and it was not

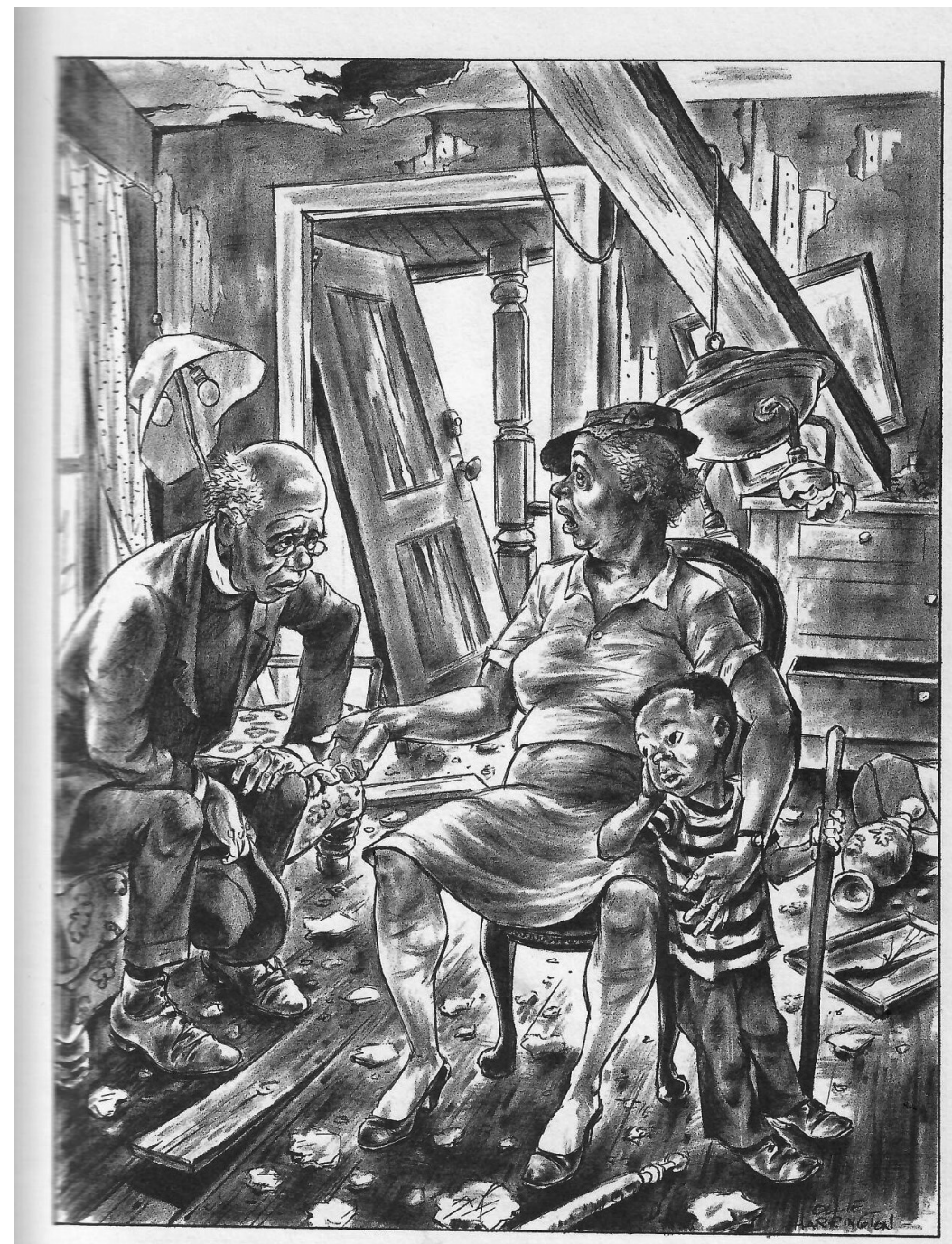

"At first we thoúght the Russians had went an' dropped one on us. You can imagine how relieved we were when we found out it was only the white citizens' Council bombin' our house agin'!"

Figure 5: Bootsie and Others: A Selection of Cartoons by Ollie Harrington (New York: Dodd, Mead, \& Company, 1958), n.p. 
the first time. While the exact location of the cartoon is not specified, it appears to be in the South based on the layout of the house, perhaps in Birmingham, Alabama, which earned the nickname "Bombingham" for the more than forty explosions set off in the homes of Black families who moved into predominantly white neighborhoods between 1947 and 1965. The cartoon focuses on how the bombing put out the lights (literally and figuratively) by picturing three destroyed lamps in the small room. The destruction of art is also emphasized as paintings lie on the floor, cracked and shattered by the force needed to blow them off the walls. They are barely visible amidst the rubble left by the blast. The grief on the pastor's face makes it impossible to find this cartoon funny. Of course, the political takeaway is that, in fact, Russia is not the enemy that poses an immediate threat; American racism is far more dangerous. On the other hand, Harrington conveys a glimmer of hope - the woman whose home has been attacked is muscular and strong. She may be sad, but she does not look like a woman who can be easily intimidated. Harrington's drawing is full and fleshy, not sketchy, giving actual weight to what the characters are saying.

Another cartoon in this collection presents police as a threat to African Americans, a stance Harrington takes up in multiple contexts. A man is explaining to his wife that he has cut a hole in the floor right behind the front door because of how often the "ofay policemens" keep breaking down doors in the neighborhood (Figure 6). In a visually compelling way, a framed picture on the apartment wall of boxer Joe Louis - known as the "Brown Bomber" and a Black Popular Front hero - shows his fists directed at the door, where the cops are threatening to come in. Louis's posture is exactly the same as the hands on the nearby clock, which suggests that the time for true resistance has come. Langston Hughes famously said of Louis,

Each time Joe Louis won a fight in those depression years, even before he became champion, thousands of Black Americans on relief or WPA, and poor, would throng out into the streets all across the land to march and cheer and yell and cry because of Joe's oneman triumphs. No one else in the United States has ever had such an effect on Negro emotions - or on mine. I marched and cheered and yelled and cried too. ${ }^{35}$

This symbolic role of Black boxers found its way into various cultural forms, for instance, there are numerous blues and R\&B songs invoking and praising them. Harrington took up boxing's symbolic role of representing African American fighting for equality and justice many times.

For example, a 1951 Freedom cartoon titled "In This Corner" depicts Sugar Ray Robinson in the boxing ring. The cartoon, for Harrington, is rather stark and bare. It shows Robinson being pelted by rocks and bottles labeled with slogans such as "Negroes not allowed," "To Ray from KKK" and swastikas-equating 


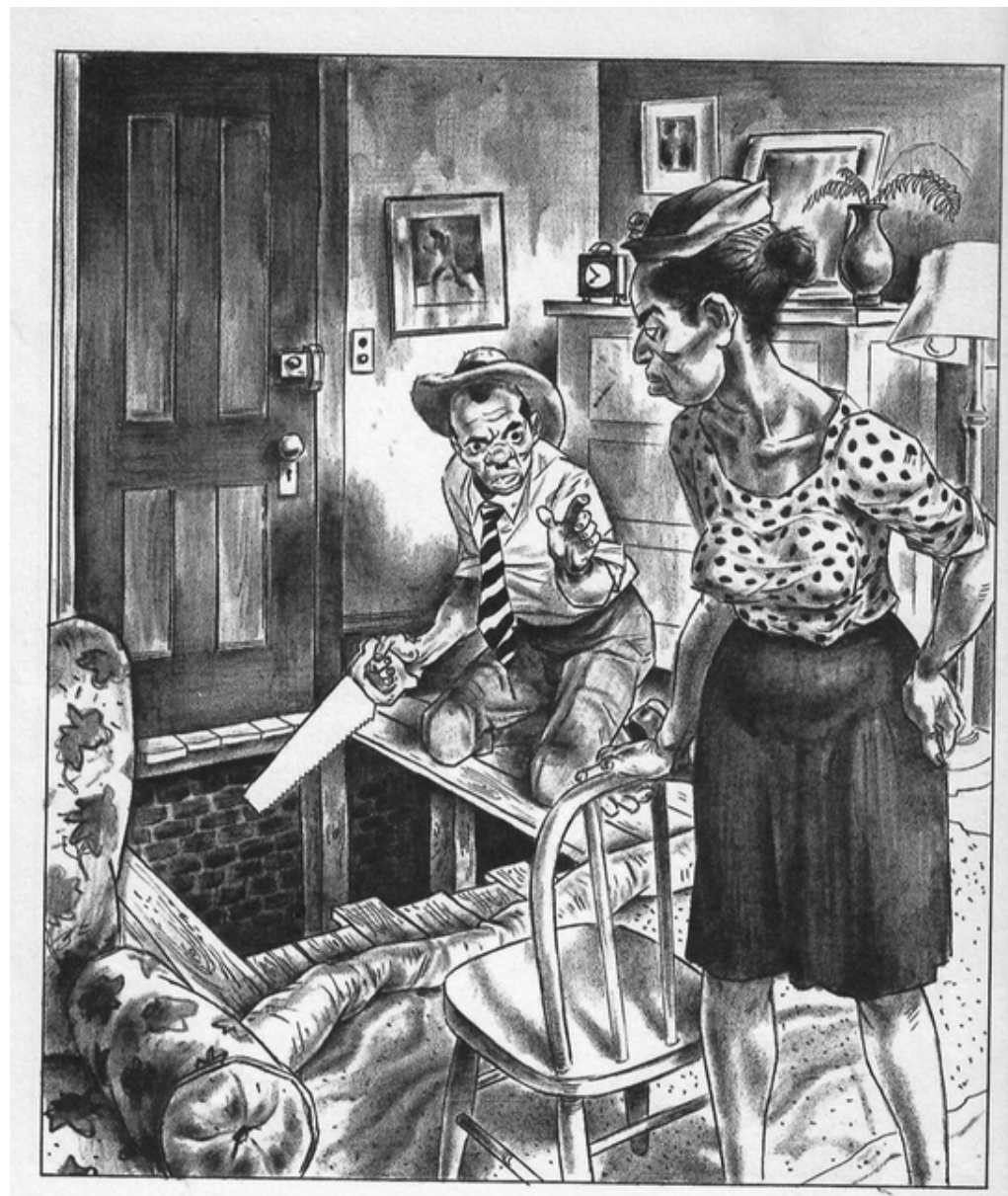

"Now look, Baby, don't come tellin' me I'm crazy. I'm just gettin' tired of the way these big fat ofay policemens is breakin' down folks's doors and jumping in all snarlin' and growlin'!"

Figure 6: Bootsie and Others: A Selection of Cartoons by Ollie Harrington (New York: Dodd, Mead, \& Company, 1958), n.p.

American white supremacy with the racial ideology of Hitler. However, Harrington's cartoon invokes serious resistance.

While the fight-back is inspiring, a more pessimistic May 1951 cartoon in Freedom is captioned, "Old Generals Never Die, They Just Fly Away” (Figure 7). This refers to a British song that introduced a saying, "Old soldiers never die, they just fade away," which in turn grew out of a gospel song, "Kind Words Can Never Die." But the cartoon came out right after General Douglas MacArthur famously used the "old soldiers" phrase in his final speech to Congress on April 


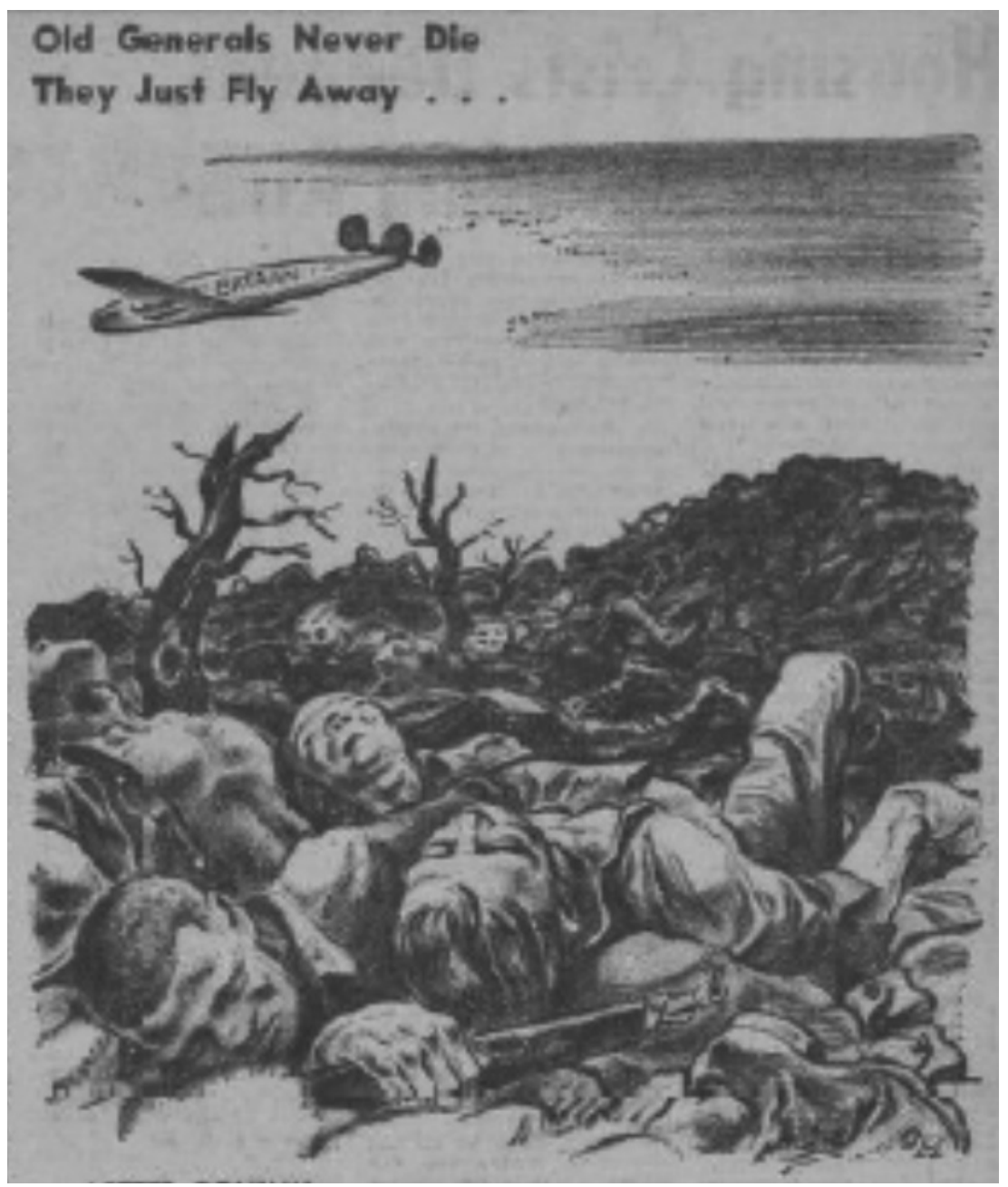

Figure 7: Freedom 1, no. 5 (May 1951), 4.

15, 1951. The cartoon slyly inverts the phrase MacArthur uses, because piles of dead and dying soldiers - both Black and white - are pictured here as being abandoned by a plane flying away with more privileged military officers. Below the plane, the cartoon is quite bleak.

There is nothing hopeful, even in a "natural" way, here. For instance, the trees have no leaves, and there is a mound in the back that is either a pile of bodies or a hill covered by dead or dying vegetation. But what is made visually clear juxtaposed against the stark backdrop are the agonized faces of the soldiers on the ground. 
As noted above, Harrington frequently pictured nooses in his Daily World cartoons; in a 1970 publication, he draws an overlapping noose and whip (Figure 8). By picturing Richard Nixon as an auctioneer of slaves, the cartoon not only visibly brings theft of African American labor into the present, but it also as-

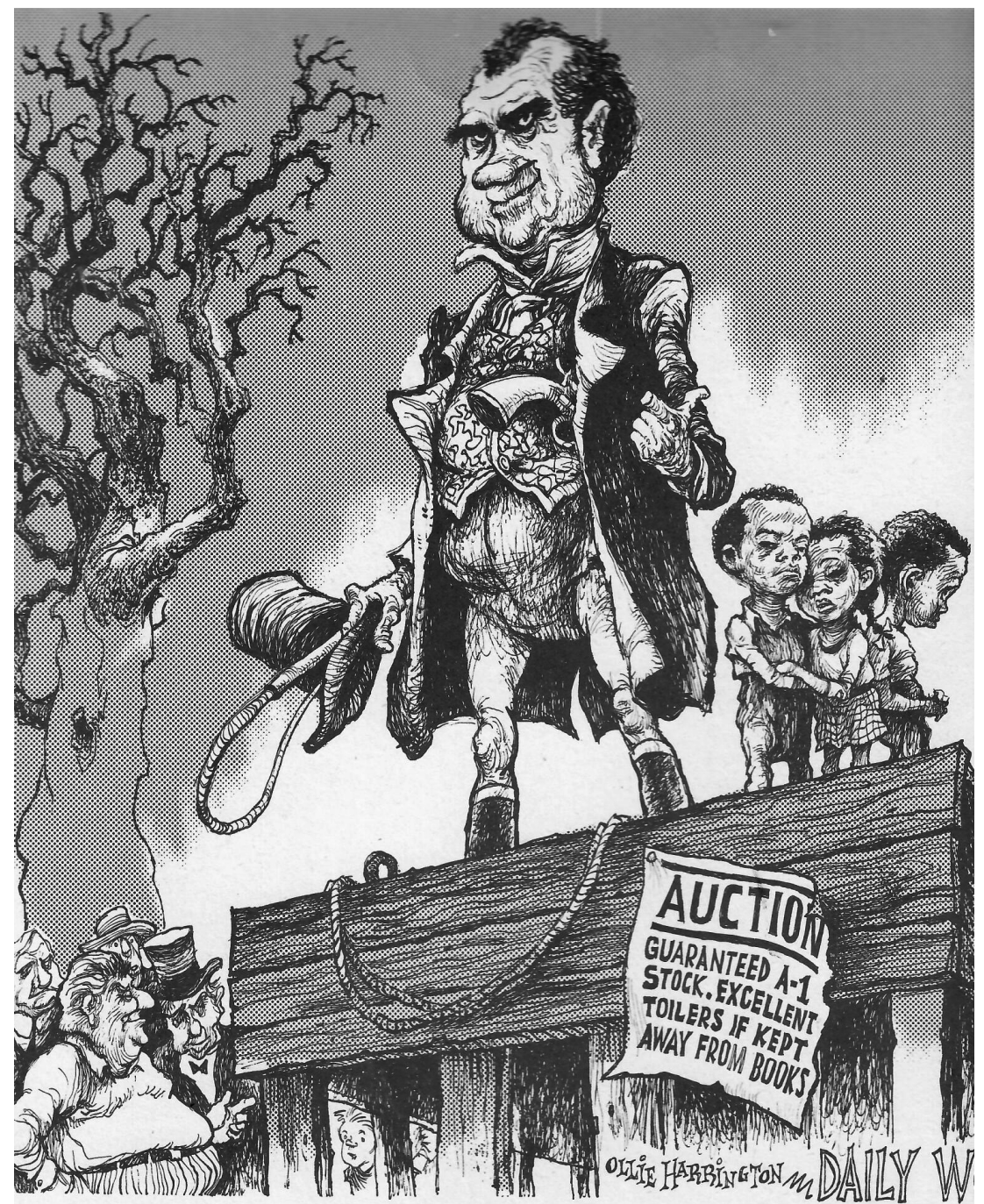

"OKAY GENTLEMEN, NOW HOW MANY 1972 DIXIE VOTES DO YOU OFFER FOR THIS EXCEPTIONAL, FINE BRACE?"'

Figure 8: Daily World, (April 1970) in Soul Shots: Political Cartoons by Ollie Harrington (printed in the GDR: Long View Publisher, 1972), n.p. 
serts that the United States' history of slavery has, at the least, a direct economic descendant. Additionally, Harrington claims that in many ways "slavery" just has a new name and new ways to perpetuate it. One of these methods is unequal access to education. A sign hanging off the stage declares that the children will be good workers as long as they are uneducated (and presumably cannot defend themselves against exploitation). Nixon's lack of pants and hairy lower body indicates that he is either a satyr (known for lasciviousness and being only partially human) or the devil. His hand is parallel to his gun and he holds it the way children do when they are playing with imaginary pistols - but in this case, it connects the work of Nixon's hand to the murder of African Americans. Further, in a simultaneously bold and gloomy image, one of the buyers wears a hat reminiscent of Uncle Sam's, visually linking slaveowners with the most familiar symbol of American patriotism. The racists are pictured as the trunk of the tree, which has many branches - indicating that there are many ways that the racism of slavery has grown and spread. The kids' faces are both hurting and defiant - which offers a tiny bit of light. Their vulnerability, though, is increased visually through their very small size.

It should come as no surprise that Harrington's radical cartooning made it impossible for him to remain in the United States. When he learned he was being investigated by the FBI, Harrington felt the need to move to Europe-first to France, and later to Sweden and the G.D.R. He did not return to visit the United States for twenty-one years. Although the pattern of African American artists moving abroad is quite familiar, with Harrington the matter is still not settled as to why he stayed in East Germany. Different answers circulate. It was "self-imposed exile" according to Elton Fax. ${ }^{36}$ Henry Louis Gates believes it was because Harrington was being investigated by the House Un-American Activities Committee (HUAC), ${ }^{37}$ while his wife, Helma Harrington, asserts he remained in East Germany because he felt "not absolutely safe" in France. ${ }^{38}$ Because of "trouble with the American authorities," his close friend Richard Wright suggested he leave France for a "socialist country." 39

Although he stayed away from the U.S. for twenty-one years, Harrington still thought of Harlem as home- but this, too, was not without conflict. In fact, the first time he came back to the United States after many years abroad, someone called him a "God damned fuckin' dumb n----r," and he thought, "Now I knew where I was...I was home Baby!"40 This brief exchange confirms what the mainstream, advertisement-filled Ebony magazine said about Harrington immediately after he died. The short memorial notes that his cartoons "tell it like it was - and is." 41 This comment, riffing on the Black expression "telling it like it is" that gained wide circulation in the United States during the 1960s, also reminds us that Harrington's work is a bridge between different moments of Black radicalism responding to Jim Crow, racism, colonialism, and neocolonialism from the Popular Front in the 1930s to Black Arts and Black Power in the 1960s and 1970s. As Brenda Gayle Plummer notes, while linking African American struggles against Jim Crow to anti-colonialism was common to almost all Black 
civil rights organizations in the U.S., from the leftwing Civil Rights Congress to the NAACP, in the 1940s, the Cold War smothered the voices of the Black Left and pressured the main Civil Rights organizations of the 1950s to fall silent on colonialism and liberation struggles of Africa. ${ }^{42}$ Because of Harrington's location in Europe, he was able to continue to link Black liberation at home with anticolonial national independence abroad in his work in a way that was difficult for African American artists still located in the United States. With the rise of the Black Power and Black Arts movements and a radical Black internationalism likewise linking liberation at home and abroad, Harrington's work circulating in Freedomways and, later, the Daily World, reminded younger Black radical artists of their forebears.

What we have tried to do here is to open a further discussion about Harrington and his art as this sort of bridge, a discussion that does not detach Harrington from his particular ideological and organizational commitments and institutional locations. More attention needs to be paid to the actual qualities of Harrington's drawings as they interface with text rather than simply focus on captions, as is all too often the case. Harrington created, with significant success, a formally and thematically radical yet popular art; his work drew on lines of Black "high," "mass," and "folk" culture (fashion, music, graphic art, dance, humor, literature, and so on) in ways that anticipated Black Arts and what came after.

\section{Notes}

1. Llewelyn Ransom, "PV's Art Editor Ollie Harrington, Creator of 'Bootsie' and "Pee Wee,' Enjoyed Life, Despite Setbacks," People's Voice, August 8, 1942, 4. Over the years, Harrington signed his work as "Oliver," "Ol," and "Ollie." For the purposes of this essay, unless we are quoting someone else, we will use "Ollie," which seems to be the name he used the most often.

2. Brian Dolinar, The Black Cultural Front: Black Writers and Artists of the Depression Generation (Jackson: University Press of Mississippi, 2012).

3. Harrington's contemporary Jackie Ormes also had strips and single-panel cartoons in the Courier and the Chicago Defender that widely circulated among Black readers, but her work was not syndicated in the way Bootsie was. Ormes's work was primarily restricted to the various editions of the Courier and the Defender.

4. Fred Carroll, Race News: Black Journalists and the Fight for Racial Justice in the Twentieth Century (Urbana: University of Illinois Press, 2017); Bill V. Mullen, Popular Fronts: Chicago and African-American Cultural Politics, 1935-46 (Urbana: University of Illinois Press, 1999).

5. Vernon L. Pedersen, The Communist Party in Maryland, 1919-57 (Urbana: University of Illinois Press, 2001), 5.

6. Langston Hughes, introduction to Bootsie and Others: A Selection of Cartoons, by Oliver W. Harrington (New York: Dodd, Mead, 1958), n.p.

7. Michael Denning, The Cultural Front: The Laboring of American Culture in the Twentieth Century (New York: Verso, 1996), xix.

8. Dolinar, The Black Cultural Front, 176.

9. Cooke's title was officially "Assistant Managing Editor," but there was no "Managing Editor" for nearly all of her tenure at the paper.

4.

10. Llewelyn Ransom, "PV's Art Editor Ollie Harrington..." People's Voice, August 8, 1942 ,

11 Hughes's poem reads, in part:

Good morning Stalingrad!

When crooks and klansmen

Lift their heads and things is bad,

I can look way across the sea

And see where simple working folks like me 
Lift their heads, too, with gun in hand

To drive the fascists from the land.

You've stood between us well,

Stalingrad!

Langston Hughes, The Collected Poems of Langston Hughes (New York: Vintage, 1995), 297.

12. John Pietaro, "Ellen Perlo and the Bold Shade of Red," The Cultural Worker, May 27, 2018. (http://theculturalworker.blogspot.com/2016/05/essay-ellen-perlo-and-bold-shades-of-red.html).

13. Oliver Harrington, Why I Left America, and Other Essays, ed. M. Thomas Inge (Jackson: University Press of Mississippi, 1993), 24.

14. Elton C. Fax, "Foreword to Oliver Harrington's Portfolio," Soul Shots: Political Cartoons by Ollie Harrington. ([printed in the GDR]: Longview Publishing Company, 1972), n.p.

15. "Tradition and Technique Are Watchwords at Yale's School of Fine Arts," Life 8 (February 12, 1940): 46 .

16. Philip Sterling, ed. Laughing on the Outside: The Intelligent White Reader's Guide to Negro Tales and Humor (New York: Grosset \& Dunlap, 1965).

17. Paul Laurence Dunbar, "We Wear the Mask," in American Negro Poetry, ed. Arna Bontemps (New York: Hill and Wang, 1963), 14.

18. A few more examples are Future's "Mask Off" and "Lil One," 2Pac's "Under Pressure," and Nicki Minaj's "Feeling Myself." The subtitle of Laughing on the Outside, which is edited by Philip Sterling, is The Intelligent White Reader's Guide to Negro Tales and Humor; this directly invokes George Bernard Shaw's 1928 book The Intelligent Women's Guide to Socialism and Capitalism, which was similarly picked up by Tony Kushner in the title of his 2009 play confronting gay characters and communism, The Intelligent Homosexual's Guide to Capitalism and Socialism with a Key to the Scriptures.

19. Hughes, Introduction.

20. Ibid.

21. See, for instance, Harrington's 1991 address at Wayne State University, "Why I Left America," in Why I Left America and Other Essays, 96-109.

22. Letters to the Editor, People's Voice, May 2, 1942, 21.

23. Ibid.

24. "Native Son: Requiescat in Pace," People's Voice, April 18, 1942, 5. It is worth noting that while some readers were worrying about what white people thought of the Native Son cartoon in a newspaper read almost exclusively by Black people, the book the strip was based on had become a bestseller and was a Book of the Month Club selection.

25. M. Thomas Inge, ed., Dark Laughter: The Satiric Art of Oliver W. Harrington (Jackson: University Press of Mississippi, 1993), 21.

26. Oliver W. Harrington, Terror in Tennessee: The Truth About the Columbia Outrages

(New York: National Association for the Advancement of Colored People, 1946).

27. Ollie Harrington, "Look Homeward Baby_Part II," Freedomways 13, no. 3 (1973): 207.

28. Inge, Dark Laughter, xxxviii.

29. Mary E. Williams, ed., Civil Rights (San Diego, CA: Greenhaven Press, 2002).

30. Sheena C. Howard, Encyclopedia of Black Comics (Golden, CO: Fulcrum Publishing, 2017), 105.

31. Ibid, 103.

32. For instance, Harrington frequently illustrates the separation of blood donations from Black and white Americans in space-filler cartoons, which continued until 1950.

33. Roi Ottley, New World A-Coming (Boston: Houghton Mifflin Company, 1943), 282.

34. Oliver Harrington, "Terror Grips War Veterans in Georgia Lynching Center," Los Angeles Sentinel, August 29, 1946.

35. Langston Hughes, I Wonder as I Wander, ed. Joseph McLaren, Collected Works of Langston Hughes, Vol. 14 (Columbia: University of Missouri Press, 2003), 307.

36. Fax, "Forward to Ollie Harrington's Portfolio."

37. Henry Louis Gates, Jr, introduction to Encyclopedia of Black Comics, ix.

38. Stephanie Brown, "Bootsie' in Berlin: An Interview with Helma Harrington on Oliver Harrington's Life and Work in East Germany, 1961-1995," African American Review 44, no. 3 (Fall 2011): 355

39. Michael Fabre, The Unfinished Quest of Richard Wright (Urbana: University of Illinois Press, 1993), 510-11.

40. Harrington, "Look Homeward Baby-Part II," Freedomways 13, no. 3 (1973), 211.

41. "The Last Laugh: Cartoons by the late Ollie Harrington tell it like it was - and is," Ebony 51, no. 4 (February 1996): 122.

42. Brenda Gayle Plummer, Rising Wind: Black Americans and U.S. Foreign Affairs, 19351960 (Chapel Hill: University of North Carolina Press, 2009), 213. 
